\title{
Studenter som medskapare av undervisning i att söka, samla och värdera information
}

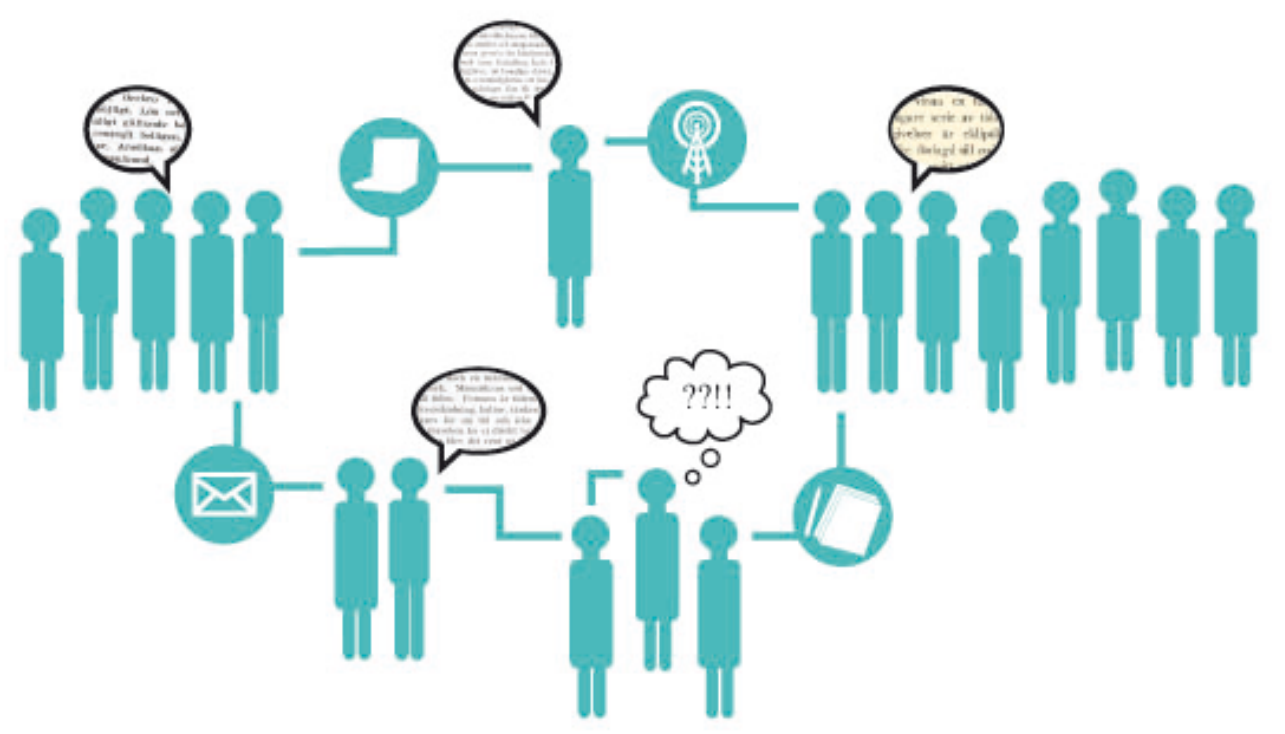




\section{Inledning och syfte}

Denna rapport redogör för ett pedagogiskt utvecklingsprojekt som biblioteket på Malmö högskola genomfört under 2014 om studenter som medskapare av undervisning $\mathrm{i}$ informationssökning. Projektet har tilldelats pedagogiska utvecklingsmedel från utbildningsberedningen. Syftet med projektet har varit att utveckla metoder för att ta tillvara studenternas erfarenheter och tidigare kunskaper för att stödja deras informationssökning. Vi har velat undersöka på vilka sätt studenterna aktivt kan involveras i undervisningen genom att titta på olika former av brukarinvolvering. Utgångspunkten har varit att ökad delaktighet leder till en djupare förståelse hos studenterna för sitt eget lärande, men också en ökad insikt hos undervisande bibliotekarier för studenternas kontext. Detta ligger i linje med Malmö högskolas strategiska plattform där det bland annat står att studenter aktivt ska stimuleras att delta i utvecklingsarbete.

\section{Projektgruppen}

Projektgruppen har bestått av fem bibliotekarier och två studenter. En av studenterna deltog endast i projektet under vårterminen eftersom han sedan bytte studieort. Studenterna har varit timanställda i projektet. Det har varit viktigt för oss att studenterna har avlönats, för att markera att värdet av deras arbete i projektet.

\section{Projektets arbetsgång}

Projektet har bestått av två delar. Under vårterminen fokuserade vi på kompetensutveckling kring brukarinvolvering genom litteraturstudier, möten och studiebesök. Under höstterminen testade vi sedan några metoder på utvalda studentgrupper. Studentgrupperna vi arbetat med har varit studenter som läst kriminologi respektive specialpedagogik. Vi har valt att arbeta med dessa studentgrupper eftersom vi redan har en etablerad kontakt och ett väl utvecklat samarbete här, och för att studenterna kommer från både grund- och avancerad nivå.

En poster om projektet presenteras på konferensen LILAC i Newcastle i april 2015.

\section{Studentdelaktighet}

Studentinvolvering kan ske i olika sammanhang. Healey et al (2014) beskriver fyra olika delar där studenter kan vara involverade: i lärande, undervisning och bedömning; i läroplansutformning; i ämnesbaserad forskning samt i utveckling av högskolepedagogik. Det här projektet har i första hand handlat om den del om som rör lärande, undervisning och bedömning.

Delaktighet och brukarinvolvering kan dessutom ske på olika nivåer. Ofta illustreras de här olika nivåerna av brukarinvolvering i en så kallad delaktighetstrappa. Ju högre upp på trappan desto mer involverade är brukarna. Delaktighetstrappan bygger på en modell av en amerikansk samhällsplanerare, Sherry Arnstein, som presenterade sin modell i en artikel från 1969. Vi har anpassat trappan för att kunna passa i ett högskolepedagogiskt sammanhang enligt följande:

Information: studenterna får information, envägskommunikation.

Konsultation: studenterna får tycka, uttrycka sina åsikter, dela med sig av erfarenheter och idéer; utifrån den information som samlats in kan lärarna sedan gå vidare och utforma undervisningen.

Dialog: studenterna får mer aktivt tycka till, vara med och resonera tillsammans med lärarna. 
Samarbete: studenterna är med och planerar undervisning, har kontroll över vissa aktiviteter men inte helheten.

Partnerskap: ett samarbete där studenterna är med och bestämmer tillsammans med lärare, delat ägandeskap.

\section{Beskrivning av metoder}

Utifrån de olika nivåerna i delaktighetstrappan lyfter vi här fram några metoder och aktiviteter som kan användas för att göra studenterna mer delaktiga i undervisningen. Några av dem beskriver vi lite mer ingående.

\section{Information}

Exempel på metoder: information på webben, lärplattformar, trycksaker, e-post.

\section{Konsultation}

Exempel på metoder: tänke-tank, enkät som underlag för undervisningsplanering, fokusgrupp, utvärdering efter undervisningstillfälle (till exempel snabbutvärdering av medstudent på Facebook).

\section{Tänke-tank}

En tänke-tank är en metod för att ge studenterna utrymme att tycka till och generera idéer i en fråga, och används för att samla in synpunkter på ett område.

Tänke-tanken inleds med att temat och syftet med tänke-tanken introduceras. Därefter arbetar studenterna individuellt, genom att enskilt reflektera och skriva ner sina idéer på post-it lappar. Efter detta börjar studenterna att arbeta i mindre grupper (4-6 deltagare). De individuella idéerna/post-it lapparna samlas in, sorteras och sätts i prioriteringsordning. Gruppen prioriterar idéerna och diskussionen dokumenteras. Avslutningsvis samlas gruppernas prioriteringslistor in och en sammanställning av gruppernas idéer görs av de som leder tänke-tanken.

Syftet är att alla studenter ska komma till tals och därför arbetar studenterna både enskilt och i mindre grupper. Som en uppföljning på en tänke-tank kan arrangörerna bjuda in till ett fördjupat fokusgruppsamtal med några av studenterna.

\section{Enkät som underlag för undervisningsplanering}

Enkäter används ofta som metod för utvärdering, men kan även användas för att samla in ett underlag för planering av undervisning. Inför ett undervisningstillfälle kan studenterna svara på en enkät med frågor kring till exempel behov, tidigare erfarenheter och förväntningar. Dessa svar kan läraren sedan använda i sin undervisningsplanering.

\section{Fokusgrupp}

En fokusgrupp är en strukturerad gruppintervju där deltagarna får frågor om sina tankar kring en viss fråga, idé, service, verksamhet etc. Det är ett sätt att få kunskap om studenternas attityder, preferenser och behov. Exempelvis kan en fokusgruppintervju genomföras efter en tänke-tank eller workshop där det kommit fram idéer och förslag på olika nivåer som man vill gå djupare in på.

\section{Snabbutvärdering av medstudent}

Detta är en form av utvärdering som görs av en student på ett mer informellt sätt för att sedan lämnas vidare till lärarna/bibliotekarierna. Metoden liknar de korta utvärderingar som kan göras muntligt eller skriftligt direkt efter ett undervisningstillfälle, men görs istället i ett forum där studenterna befinner sig som till exempel Facebook. 
Att utvärdera genom att ställa frågor i ett forum som Facebook kan vara ett sätt att sänka tröskeln för delaktighet. Att frågan ställs av en medstudent skulle kunna innebära att svaren blir ärligare och att studenterna inte känner lika stor press att säga något "bra" utan kan vara mer öppna. Det finns också möjlighet för andra studenter att se vad som sagts så att de antingen kan reagera på detta, hålla med eller kommentera något annat. Det här kan dock vara svårt att genomföra om inte studenterna som ställer frågorna befinner sig i ett tydligt sammanhang och har en tydlig roll, till exempel deltar $\mathrm{i}$ lärarlaget. Det är viktigt att studenterna inte känner sig utsatta och upplever att de går lärarens ärenden.

\section{Dialog}

Exempel på metoder: referensgrupp, knytkonferens.

\section{Referensgrupp}

En referensgrupp består av studenter som återkommande träffas och tillfrågas om för kursen relevanta frågor.

\section{Knytkonferens}

En knytkonferens, även kallad unconference, drivs av deltagarnas intressen och engagemang. Ingen bestämd dagordning finns utan den sätts tillsammans. Det enda som är givet på förhand är plats, tid och ett övergripande tema.

Konferensen startar med att deltagarna skriver ner på post-it lappar det de önskar prata om relaterat till temat. Deltagarna får sedan presentera de samtalsämnen de vill ta upp. Lapparna klistras därefter upp på en anslagstavla och liknande teman sätts samman. Deltagarna antecknar sig på de diskussioner de vill delta i. Om det blir för många samtalsteman i förhållande till tillgängliga lokaler och deltagare kan det röstas om vilka teman man vill behålla. Deltagarna deltar därefter i de diskussioner de är intresserade av och har både rätt och skyldighet att gå vidare till en annan diskussion när de inte tycker sig ha mer att tillföra eller få ut av samtalsämnet.

\section{Samarbete}

Exempel på metoder: idéverkstad, arbetsgrupp/projektgrupp, gemensam undervisnings-/kursplanering.

\section{Idéverkstad}

Idéverkstad är en metod som syftar till att ta fram idéer och strategier för att också förverkliga dem. Utgångspunkten är ett gemensamt tema eller en frågeställning som bearbetas i mindre grupper. Formen påminner om tänke-tanken som vi redan nämnt, men i idéverkstaden har deltagarna större inflytande över hur idéerna förvaltas och drivs vidare. Idéverkstaden måste avslutas med en tydlig överenskommelse kring hur arbetet ska fortsätta.

\section{Arbetsgrupp/Projektgrupp}

Studenter är med i en arbetsgrupp eller i en projektgrupp. Det kan till exempel vara att en eller flera studenter är med i ett pedagogiskt utvecklingsprojekt på samma sätt som vi i vårt projekt har haft med en student i projektgruppen. Det skulle också kunna vara att en eller flera studenter deltar i en arbetsgrupp tillsammans med lärare/lärarlag som arbetar med kursplanering.

\section{Gemensam undervisnings-/kursplanering}

Lärare och studenter planerar tillsammans och lägger upp ett tillfälle/flera tillfällen 
utifrån de mål som finns för kursen. För att förbereda studenterna på själva planeringen kan man börja med att inventera deras tidigare erfarenheter och idéer om lärande.

\section{Partnerskap}

Exempel på metoder: studentledd undervisning, studenter utformar och leder kurser.

\section{Testade metoder i projektet}

Den andra delen i projektet handlade om att testa några av de metoder vi kommit i kontakt med via litteratur, möten och studiebesök. Detta har vi gjort på följande sätt:

\section{Facebookutvärdering via student på kriminologiprogrammet}

För att utvärdera ett särskilt undervisningstillfälle testade vi att lägga ut en förfrågan $\mathrm{i}$ studenternas facebookgrupp. Detta gjorde vi genom att en av våra studenter $\mathrm{i}$ projektgruppen, som också deltagit i bibliotekets undervisning, bad sina kurskamrater om återkoppling på undervisningstillfället i ett inlägg via kursens grupp på Facebook. För bibliotekariernas del gav det en ärligare respons på undervisningstillfället än vad vi tror att vi fått med en mer traditionell utvärdering.

\section{Tänke-tank på specialpedagog-och speciallärarprogrammen}

Vi genomförde en tänke-tank med studenter som läser termin 5 på speciallärar- och specialpedagogprogrammen. Syftet var att samla in studenternas tankar och önskemål om hur biblioteket skulle kunna vara en resurs för studenterna under utbildningen. Detta fick de göra genom att utgå från de mål i högskolelagen och examensordningen som relaterar till att kunna söka och värdera kunskap på vetenskaplig nivå samt ha insikt i aktuellt forsknings- och utvecklingsarbete.

De studenter som valde att delta var mycket engagerade och vi fick in väldigt många intressanta tankar, förslag, idéer och önskemål som vi kan använda för att utveckla bibliotekets verksamhet. Alla studenter hade dock inte uppfattat syftet med idéverkstaden, samt att den inte direkt hängde ihop med föreläsningen innan eller var en del av deras uppgift.

\section{Undervisningsplanering tillsammans med kriminologistudenter (Kriminologi II)}

Tanken var att ha en idéverkstad tillsammans med studenter som läser kriminologi . Studenterna läste Kriminologi II och skulle skriva ett fördjupningsarbete. Kursen är en fristående kurs och hade under hösten haft ca 20 deltagare.

Syftet med idéverkstaden var att studenter och undervisande bibliotekarier tillsammans skulle planera ett obligatoriskt undervisningstillfälle i litteratursökning ett par veckor senare. Upplägget för idéverkstaden knöt an till kursens pedagogiska grundsyn där studenten uppmanas att vara aktiv i sitt eget lärande. Vi utgick även ifrån aktuella lärandemål och uppgiftsbeskrivning för kursen.

Endast en student dök upp, vilket gjorde att vi inte kunde genomföra idéverkstaden. Istället skickade vi en enkät till studenterna i kursen. Svaren från denna kunde sedan den bibliotekarie som undervisade på kursen ha som underlag för lektionen.

\section{Avslutande reflektioner}

I vårt projekt har vi velat undersöka hur studenter aktivt kan involveras i undervisningen genom olika former av brukarinvolvering. Att göra detta har varit mycket lärorikt. En av de stora vinsterna med projektet har varit att projektgruppen bestått av både bibliotekarier och studenter. Detta har gett både studenterna och bibliotekarierna $\mathrm{i}$ projektgruppen möjlighet att få bättre förståelse för varandras kontexter. 
Projektgruppens kompetens har också blivit bredare än vad den skulle varit med bara bibliotekarier. Att vi i projektgruppen kommer från två olika sammanhang har också inneburit att sådant som tagits för självklart har behövts diskuteras, tydliggöras och ibland även omprövas.

När vi testat metoder har vi fått många nya idéer och tankar kring hur vi kan utveckla vår undervisning och vårt pedagogiska stöd. Exempelvis gav tänke-tanken som vi genomförde med specialpedagog- och speciallärarstudenterna en bra insikt $\mathrm{i}$ studenternas erfarenheter samt massor av uppslag till hur vårt pedagogiska stöd till studenterna skulle kunna se ut och utvecklas.

En lärdom vi dragit i projektet handlar om hur viktigt det är att vara tydlig med vad man som student kan vara med och påverka och vad man kan förvänta sig att få tillbaka. Det är viktigt att studenterna förstår frågan och syftet, varför vi vill att de ska vara delaktiga och vad resultatet ska användas till. Det är därför viktigt att förbereda och introducera studenterna grundligt.

Att arbeta med studentinvolvering har också inneburit flera svårigheter. Ett dilemma har varit att engagera studenterna och få dem att delta i de aktiviteter vi arrangerat. Detta tror vi beror på flera saker. För det första är inte biblioteket en tillräckligt integrerad och självklar del i utbildningarna, och det vi försökt göra har uppfattats som något separerat från resten av kursen. Workshopen som vi fick ställa in visade sig också komma väldigt nära en deadline för en inlämningsuppgift som vi tror studenterna prioriterade.

För att lyckas med studentinvolvering tror vi att det krävs en deltagarkultur där det faktiskt är möjligt att påverka. Brukarinvolvering handlar inte bara om metoder, utan det handlar även om att alla inblandade har en inställning som stödjer ökad studentdelaktighet. I Malmö högskolas strategiska dokument står att studenter aktivt ska stimuleras att delta i utvecklingsarbete. Det framgår dock inte vad detta egentligen innebär eller hur och i vilka sammanhang detta ska ske. För att ett partnerskap ska motiveras måste det finnas tydligare riktlinjer och en tydlig vinst för alla inblandade. När projektet inleddes trodde vi att vi skulle testa fler metoder än vi hunnit med i praktiken. En anledning till det är att vi behövt ägna mycket tid i projektgruppen åt att komma in $\mathrm{i}$ tankesättet kring brukardelaktighet. Det är inte bara att sätta igång och testa metoder, utan det kräver kunskap och ett medvetet förhållningssätt.

\section{Referenser}

Arnstein, Sherry. 1969. A ladder of citizen participation. Journal of American Institute of Planners, 35(4): 216-224

Healey, Mick, Flint, Abbi och Harrington, Kathy. 2014. Engagement through partnership: students as partners in learning and teaching in higher education. The Higher Education Academy. https://www.heacademy.ac.uk/sites/default/files/resources/Engagement_th rough_partnership.pdf (Hämtad 2015-03-06)

Malmö högskola. Strategi 2020. http://strategi2020.mah.se/ (Hämtad 2015-03-24) 